\title{
'Green shift': an analysis of corporate responses to climate change
}

\section{Gareth Dale}

School of Social Sciences,

Brunel University,

Uxbridge, Middlesex UB8 3PH, UK

E-mail: gareth.dale@brunel.ac.uk

\begin{abstract}
The concept of climate change is now of global concern. This article explores corporate responses through an investigation of the rhetoric of several major UK companies that claim to be leading corporate adjustment. It argues that their actual business practice fall far sort of the claims made for it. This raises questions about the extent to which solutions based on a philosophy of market and business solutions is capable of either meeting the ends claimed for it or confronting the scale of the problem of climate change. The difficulty, however, is that in the competition of when corporate claims are allow to compete, bad solutions might be diverting attention from and even driving out good solutions.
\end{abstract}

Keywords: biofuels; BP; carbon trading; climate change; climate change strategies; greenwash; Marks and Spencer; Tesco; Virgin.

Reference to this paper should be made as follows: Dale, G. (xxxx) 'Green shift': an analysis of corporate responses to climate change', Int. J. Management Concepts and Philosophy, Vol. x, No. x, pp.xx-xx.

Biographical note: Gareth Dale is a Senior Lecturer in Politics and International Relations. He received his doctorate from the University of Manchester and worked at the London School of Economics and at Swansea University before joining the School in 2005. His research interests are in the political economy of climate change, international political economy, Karl Polanyi, German politics and international migration. His publications include The European Union and Migrant Labour (co-edited with Mike Cole); a triology on the history of the East German economy. Currently, he is writing a monograph on the life and work of Karl Polanyi.

Until Al Gore came to his door in 2006, Richard Branson had not been greatly troubled by the prospect of climate change. But, on that day he experienced his 'Road to Damascus' (Branson, 2007a). Nothing, he reflects

"wakes one up more to the issues at hand than the former vice president of the USA coming all the way to your home in London to give a personal lecture on global warming. ... Looking directly at me, he said, "Richard, you and Virgin are icons of originality and innovation. You can help to lead the way in dealing with climate change. It has to be done from the top down, instead of from the bottom up on a grassroots level (Branson 2007 a,b)"'.

Listening to Gore's lecture, the Virgin tycoon came to see that drastic cuts in greenhouse gas emissions are imperative or 'in a very short space of time most of the Earth will be 
uninhabitable' (Branson 2007a). Acting swiftly upon this epiphany, he launched a \$25 million prize for the originator of the most convincing invention for actively absorbing and storing $\mathrm{CO}_{2}$. His company now pioneers a new approach to marrying the needs of business and the environment, which Branson dubs 'Gaia Capitalism.'

Branson is unusually adept in the arts of self-dramatisation and headline-grabbing but his conversion belongs to a wider trend, the green revolution in the boardrooms of bluechip corporations. Scarcely, a week goes by without media reports of new climate-change mitigation strategies and achievements. In 2007, Virgin was joined by HSBC, which announced that it had attained 'carbon neutrality,' by Barclaycard, which donates half the profits of a new credit card to projects that tackle climate change, and many more. 'Big companies from BSkyB to the banks and the oil majors,' commented the Guardian, 'have been vying to underline their green credentials and portray themselves as caring, sharing protectors of the planet' ${ }^{1}$. The green shift is mirrored within business institutions. The new head of the Confederation of British Industry, according to Jonathon Porrit, 'talks about climate change in a very different way from his predecessor, Digby Jones. Ben Verwaayen, chief executive of BT, now chairs the CBI's taskforce on climate change and hopes are high that its recommendations will drag the CBI membership into something vaguely resembling reality ${ }^{2}$. Even the chief sponsor of climate-change denial has begun to shift. 'The US and European institutional investors worth \$700bn,' the Financial Times revealed, led a charge 'to oust an Exxon board member for 'inaction' on climate change.' The ExxonMobil executive had repeatedly refused to discuss the company's controversial climate strategy with them. They intended, the investors announced, to support shareholder resolutions requesting specific emissions reduction goals and higher spending on renewables ${ }^{3}$.

For some analysts, these developments amount to a 'corporate climate change campaign'4. Noble (2007) draws attention to the mushrooming of institutions devoted to lobbying for business-friendly climate change regulation. One such is the Business Environmental Council, which emphasises that

$$
\begin{aligned}
& \text { "climate change should be dealt with through 'market-based mechanisms' and } \\
& \text { by adopting 'reasonable policies,' and expressed the belief 'that companies } \\
& \text { taking early action on climate strategies and policy will gain sustained } \\
& \text { competitive advantage over their peers." }
\end{aligned}
$$

Another is the Partnership for Climate Action, the purpose of which is, in its words, 'to champion market-based mechanisms as a means of achieving early and credible action on reducing greenhouse gas emissions that is efficient and cost-effective.' These were joined more recently by the US. Climate Action Partnership, whose 'Call for Action' identifies the 'urgent need for a policy framework on climate change' and emphasises that 'a mandatory system is needed that sets clear, predictable, market-based requirements to reduce greenhouse gas emissions.'

In this article, I examine the corporate green shift. I summarise the emissions reduction strategies of four corporations: BP, Marks \& Spencer (M\&S), Tesco and Virgin. For each, I outline their action plan and, where pertinent, the claims made for it by company spokespeople, and then proceed to analysis and critique. The sample is selected according to two criteria: it includes large corporations, which unambiguously position themselves as environmental pioneers. All four were rated by consumers as among the 'top twenty' green firms in a recent survey'. 


\section{Climate-change strategies: BP, Marks \& Spencer, Tesco and Virgin}

From 1995 to 2007, BP's CEO was John Browne, who frequently professed an urgent concern for global warming ('climate change is a risk we cannot ignore - We have to act now' $)^{6}$. Under Browne's leadership the company renamed itself 'Beyond Petroleum,' adopted its distinctive sunflower logo, and promised not to invest in oil extraction from tar sands. In addition to research and lobbying, BP's climate-change strategy has four planks: renewables, biofuels, carbon sequestration and offsets.

Renewables. BP is one of the world's largest producers of solar photovoltaics. It intends to invest $\$ 8$ billion over the next ten years in renewable energies.

Biofuels. In Britain, BP is ramping up biofuel production, with a new plant that will use some of what it terms Britain's 'wheat surplus,' producing fuel with $\mathrm{CO}_{2}$ emissions at least $40 \%$ lower than fossil equivalents. It is funding research on biofuel feedstocks by Mendel Biotechnology. It has established a demonstration project for jatropha, a biofeedstock, and a bio-diesel refinery, and plans to invest approximately $\$ 160 \mathrm{~m}$ in a joint venture with biofuels firm D1 Oils, to include the creation of over one million hectares of jatropha plantations in India and Africa ${ }^{7}$.

Carbon sequestration. In Algeria, $\mathrm{BP}$ operates a $\mathrm{CO}_{2}$ capture and storage project that will 'decarbonise' natural gas, releasing hydrogen for use in power production. The captured

$\mathrm{CO}_{2}$ is injected into geological reservoirs.

Offsets. BP has invested in a variety of offset projects. Its website recently highlighted one such scheme for trapping and burning the methane emissions from pig farms in Mexico, equating to the emissions of 750,000 cars per year.

The next two companies are in the retail sector, beginning with M\&S. Consumers' decisions, according to its Head of Corporate Social Responsibility, are increasingly motivated by 'ethical' concerns. Internal research indicates that, whereas 'Four years ago $50 \%$ of customers said it mattered to them that M\&S was a responsible business, by last year that proportion had grown to $97 \%{ }^{, 8}$. The company has committed to numerous green initiatives, including reduced packaging, manufacturing fleecy jackets from recycled plastic bottles and launching a 'Carbon Challenge' with the Women's Institute and World Wildlife Fund to help customers reduce their carbon emissions. But, its key climate change commitments can be grouped under five headings.

Renewables. M\&S pledges to 'maximise our use of renewable energy,' including the goal of 'powering all our UK with green energy from a variety of sources, including 'anaerobic digestion',

Biofuels. M\&S promises to ban petrol-fuelled company cars and to ensure that 'all our lorries run on at least $50 \%$ bio-diesel.'

Localisation. M\&S is committed to sourcing 'as much food from Britain and Ireland as we can and to setting targets 'to reduce the amount of food we import by air.'

Labelling. M\&S plans to introduce carbon labelling, spelling out the 'carbon cost' of products. It will put an aeroplane symbol on air-freighted food products. 
Offsetting. In its 'Five-Year Plan' announced in 2007, M\&S declares that it will buy carbon offsets 'as a last resort where no green alternative exists' - for example with airplane fuel and home furniture deliveries.

As a result of these and other measures in its green 'Five-Year Plan' - which M\&S estimates will cost $£ 200$ million over five years - the company hopes to become carbon neutral by 2012 and to be recognised as Britain's 'greenest retailer.' That crown is, needless to say, disputed by other chains, including Tesco.

Tesco's key commitments can be summarised under four headings:

Energy efficiency. The company promises that a range of measures will halve its energy use per square foot between 2000 and 2010.

Renewables. Tesco is to inject $£ 100 \mathrm{~m}$ into experimental projects to supply energy to its stores from wind turbines, solar panels, geothermal power and gasification (power from waste food) $)^{9}$.

Biofuels. Tesco has acquired a major stake in Greenergy, a leading biofuels producer, and intends to convert its entire distribution fleet to bio-diesel. It already uses $5 \%$ biofuel in its petrol at 185 filling stations.

Labelling. Tesco plans to publish a 'carbon count' on its packaging.

Virgin's strategy can be summed up in one word: technology. One thinks of Branson's prize, and Virgin Atlantic's recent purchase of new, less fuel-inefficient, Boeing 787s. Then, there is Branson's advocacy of nuclear power as a low-carbon energy source, and his suggestion that his space-tourism enterprise, Virgin Galactic, may help with its shortcomings ("The biggest problem with nuclear power is knowing how to deal with the waste. Maybe if our space programme gets going we could send it off into the sun ...' $)^{10}$. But, the technology upon which Virgin bets by far its highest stakes is biofuel. Entering this sector, writes Branson (2007b), offers hope for the climate and 'should be a good business move - investing in [biofuels] puts pressure on fossil fuel prices and acts as a hedge for our airline and train companies.' In 2007, when headlines announced 'Branson to invest $\$ 3 \mathrm{bn}$ to fight global warming' they were referring to investment in biofuel development and production. Virgin had already announced its backing for a Californiabased bio-ethanol producer, Cilion, and this was followed by the launch of Virgin Fuels, which plans to invest up to $\$ 400 \mathrm{~m}$ in bio-fuel projects ${ }^{11}$. Virgin Trains include bio-diesel in their fuel mix, while Virgin Atlantic is to form an alliance with Boeing and General Electric to develop biofuels for aero engines. In this, Virgin hopes to achieve commercial viability within five years, and has already succeeded in flying a plane on a fuel mix that included some biofuel. For these initiatives Branson has received widespread acclaim, notably in Nicholas Stern's (2007) 'Economics of Climate Change' Review, and in 2007, 'Concerned Consumers Survey' Virgin Atlantic scored highest, on the question of green credentials, of the five airlines listed ${ }^{12}$.

\section{Analysis: BP, Marks \& Spencer, Tesco and Virgin}

Such are the strategies. I turn now to examine their efficacy. Which of them consist mainly of spin and exaggeration, and which will make a real impact? 
For BP, it is appropriate to put its mitigation strategies in perspective through comparison with its responsibility for generating climate change. Together with Shell, the company accounts for an astounding $40 \%$ of the $\mathrm{CO}_{2}$ emissions of all FTSE100 companies $^{13}$. Yet, of its new investment, only $2-3 \%$ goes on renewables. Its investment in biofuels in Britain will supply about a third of that country's total demand by the end of the decade and may or may not contribute to climate change - this issue is analysed below - but either way the sum involved represents 'petty cash' for a company of its size, according to the Financial Times ${ }^{14}$. On offsets, BP has recently been accused of exaggerating cuts in emissions from Mexican pig farms: the methane savings, it turns out, will be a small fraction of the predicted levels. BP admits the anticipated savings 'will not be reached' and has corrected the claims on its website ${ }^{15}$. As regards carbon sequestration, critics point out that it is expensive, and perceived as potentially viable only because the $\mathrm{CO}_{2}$ extracted is injected into depleted oil fields in order to pump more oil, releasing even more $\mathrm{CO}_{2}$. The procedure is also risky. 'If we put this stuff away for thousands of years,' wonders Nick Riley of the British Geological Survey (McGarr, 2005), 'then what happens if it leaks?' BP has retreated from its earlier promise, and will be investing nearly $£ 1.5$ billion in a joint venture to produce oil from Canadian tar sands. Extracted using high-temperature steam, this oil is upto five times more energy-intensive than traditional forms of production. 'By jumping into tar sands extraction,' a Greenpeace Canada spokesperson told the Independent (Milmo, 2007), BP 'is taking part in the biggest global warming crime ever seen and its green sheen is gone.' Finally, on public policy, BP's claims to exert a positive influence are open to challenge. In the USA, the oil giant has actually lobbied to block legislation to introduce curbs on GHG emissions (Harriss-White and Harris, 2007). It is unquestionably a key player in carbon trading policy formation, but the efficacy of such schemes is questionable, as will be discussed below.

For M\&S, its Five-Year Plan has been widely acclaimed. The campaigns director of Greenpeace UK enthuses that 'if every retailer in Britain followed M\&S's lead it would be a major step forward in meeting the challenge of creating a sustainable society ${ }^{16}$. It does undoubtedly mark a strategic shift, yet it can scarcely be described as major: the cost over five years will be less than $0.5 \%$ of just one year's turnover. M\&S's primary commitment, biofuels, will be discussed below; here I concentrate on two others: offsetting and labelling.

Offsetting is utilised by businesses (like BP) whose profit margins depend upon delaying a transition to a low-carbon economy for as long as possible and by those (like M\&S) for which an 'ethical' profile matters. The best that can be said of it is that it enables some projects - e.g. in renewable energy - to become viable that otherwise may not be; plus, it may bring extra investment to poor countries. Its shortcomings, however, are legion. Offset schemes are virtually unregulated, and different companies quote sharply divergent prices for offsetting the same quantity of emissions. Much offsetting involves funding energy efficiency projects, which begs the question: would these improvements not have occurred anyway? One investigation of offsetting within the Clean Development Mechanism (CDM; a carbon trading system to be discussed below), exposed the case of a giant steel mill, run by an Indian company, Jindal (Davies, 2007):

"It had put forward three separate projects, all of which would capture waste heat and funnel it back into the mill as a source of energy. But the company insisted it could afford to do this only if the scheme was accepted by the CDM. [An advisor to the CDM board], however, found the mill had decided to do this 
years earlier and accused Jindal of making statements which were 'blatantly wrong'. He warned the CDM board that the evidence showed Jindal would have gone ahead with the three schemes on purely commercial grounds and were, he reported, 'clearly nonadditional'. But the board accepted the projects whose supposed cuts in carbon emissions are now being used to allow extra emissions, mostly in Europe".

The other typical offset scheme is forestry. Trees do absorb $\mathrm{CO}_{2}$, yet at a low level relative to fossil-fuel emissions: in order to absorb just the USA's current $\mathrm{CO}_{2}$ emissions $31 \%$ of that country would have to be planted with new forest (Warr, 2006). Forest cover, being less reflective than other forms of land surface, traps extra heat (except, to a small extent, in the tropics). Tree planting requires land draining and clearance, releasing carbon. Most new forests are monocultures, requiring high water, fertiliser and pesticide inputs to thrive. Moreover, for carbon to be fixed permanently the 'offsetting' trees must not die and rot, or burn; and if protected from loggers these must not be displaced to another forest.

Offsetting, critics contend, offers high-polluting industries the opportunity to 'greenwash' their activities. The schemes involve financing projects that are in any case necessary; they typically involve exploiting the North-South emissions and incomes gaps: companies in the North increase emissions, but assuage their critics and corporate consciences by paying for cheap emissions reduction projects in the South. In essence, this amounts to 'offsetting' developed-world pollution against the underdevelopment of others $^{17}$. The overall effect of offsetting is to legitimise carbon emissions - a truth that is expertly satirised by cheatneutral.com, a website that offers disloyal partners the prospect of offsetting their infidelities by paying money to couples who pledge to stay faithful ('First you should look at ways of reducing your cheating. Once you have done this you can use Cheatneutral to offset the remaining, unavoidable cheating').

As with offsetting, labelling may produce a small effect, at the margin. Yet, even this initiative has significant drawbacks. If customers are ignorant when information is scarce the provision of additional statistics for each product may merely induce bewilderment and paralysis. Carbon footprints are notoriously difficult to measure. (Should, for example, that of a bottle of orange juice includes the nitrous oxide - a greenhouse gas 300 times more potent than $\mathrm{CO}_{2}$ - emitted by artificial fertilisation of the oranges?) In addition, many consumers show little trust towards corporations. One recent survey of over 2,700 people in Britain and America suggests that the recent wave of corporate greenery will have little impact on consumers 'because nine out of 10 consumers are sceptical' about the information they receive from companies and governments (This contrasts with $60 \%$ who trust scientists and almost half who put the same faith in environmental groups $)^{18}$. But, the most important limitation of labelling is that all but the wealthiest consumers are aware that as individual consumers their influence is negligible. This problem will actually be exacerbated by carbon labelling, for it represents an attempt by corporations to delegate responsibility for combating climate change to individuals. This, Heather Rogers suggests (2007), should be understood in the light of past businessled campaigns against litter and for recycling. The latter campaign, she writes, served to 'ingrain a sense of personal culpability for increasing levels of trash ... the rhetoric of recycling targeted individual behaviour as the key to the garbage problem, steering public debate away from the regulation of production.' The current discussion of individual 'carbon footprints' - to which carbon labelling belongs - is an extension of the same tendency. 
As for Tesco, its commitment to halving its energy use per square foot by $50 \%$ may be laudable, but given its outlets' rapidly expanding acreage the results are less impressive in absolute terms. Moreover, the degree to which energy efficiency initiatives are genuinely 'green' is open to question. In a widely cited article entitled 'green is the new black,' Tesco's CEO Terry Leahy (2007) claims that they are. The article addresses the question (as phrased - hardly impartially - by Leahy): "Why now? Why has Tesco suddenly taken on a role as a leader in the environmental debate? Isn't this all just opportunism, or 'greenwash'?' His argument, in essence, is that the key techniques of mitigating climate change are identical with those designed to reduce energy and materials costs. Tesco, he concludes,

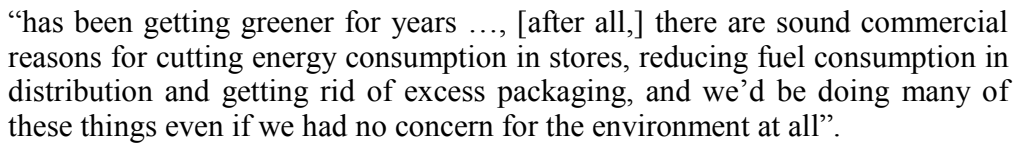

Although Leahy's avowed intention is to counter accusations of 'greenwash,' in admitting that Tesco would 'be doing many of these things even if it had no concern for the environment at all' he gives the game away, effectively conceding the argument to those critics who accuse his firm of painting actions taken for 'sound commercial reasons' green in order to pre-empt pressure to introduce measures that, while seriously addressing climate change, could impair profitability.

The principal shortcoming of Tesco's strategy, however, is that it does not address transport, except through use of biofuels ${ }^{19}$. Tesco and its cousins have developed an exceedingly fuel-intensive business model involving centralised distribution networks, meaning that produce is trucked up and down the country from big warehouses. (Vegetables in its stores travel an average 600 miles before they reach the customer). Tesco's trucks clock 68 million miles each year, with rail transportation of goods only $1.2 \%$ of this. In addition, it air freights millions of tonnes of products around the world. Tesco supports industrial - fossil fuel-intensive - agriculture; and its stores are located to facilitate access by car - many are out of town. As Tesco expands, smaller local shops shut down, forcing customers to drive further. When this model was threatened by a government proposal for a tax on out-of-town parking, Tesco rounded on and defeated the proposal. A final limitation of Tesco's strategy - and indeed of the other firms under discussion - is that the promises are not copper-bottomed. As George Monbiot points out, in an open letter to Terry Leahy, 'At no point in your [Corporate Responsibility Review] do you explain which - if any - of the cuts you list have been independently audited. Without auditing, we have no guarantee that your claims are anything but spin ${ }^{20}$.

Finally, we come to Virgin. Few developments symbolise the corporate green shift better than Branson's damascene conversion to 'Gaia Capitalism'. Of the tools with which Virgin proposes to tackle climate change, the one that has hit the headlines is the 'Earth Challenge' prize: to be awarded to any individual or group developing a commercially viable technology capable of removing $\mathrm{CO}_{2}$ and other greenhouse gases at the rate of at least one billion tons per annum over a decade. So far, two technologies appear to be serious candidates. One is the so-called 'synthetic tree,' that would use caustic soda to filter $\mathrm{CO}_{2}$ out of the air; its inventor estimates that 250,000 such trees would be needed to soak up the $\mathrm{CO}_{2}$ produced worldwide annually. The other is seeding relatively lifeless parts of the oceans with iron filings (or urea) to stimulate phytoplankton 
growth. About $25 \%$ of the carbon absorbed, its advocates predict, would sink to the bottom.

Yet both of these technological fixes face major obstacles. Assuming it ever leaves the drawing board, the major obstacle facing synthetic trees would be the energy expended in creating and processing the chemicals (the second law of thermodynamics springs to mind). Massachusetts Institute of Technology engineer Howard Herzog estimates that this alone would make the trees unviable ${ }^{21}$. As to ocean seeding, scientists have cast doubt on the prediction of $25 \%$ absorption. Empirically, the small-scale openocean trials that have been conducted to date have not demonstrated sequestration into the deep ocean. Rather, they found that zooplankton multiplied too, consuming the phytoplankton and releasing $\mathrm{CO}_{2}$. In addition, the danger is that it would produce massive unwanted side effects in marine ecosystems. If iron seeding were to go commercial, scientists warn, it 'could cause substantial harm to the ocean ecosystem and may even reduce its ability to sequester carbon, ${ }^{22}$. A further problem, highlighted in Nature by Irina Marinov and colleagues, is that stimulating phytoplankton production in one part of the ocean can act to depress it elsewhere ${ }^{23}$.

Regrettably, the likelihood of a technology being devised that would allow extraction of greenhouse gases from the atmosphere rapidly enough and in volumes of sufficient magnitude to significantly restrict climate change is minimal. For technological fixes in general, the hazard is that they create a costly smokescreen for continued reliance on fossil fuels and divert funds from investment in proven technologies such as renewable energy, building insulation and public transport. This provides a clue as to why Branson, of all billionaires, is the one to step forth with his prize: not one of the technologies and domains just listed applies to aviation. The Earth Challenge initiative 'may hold particular appeal in the aviation industry as there really are no other viable, cleaner fuels in the pipeline,' suggests Steve Rayner, a professor of science and civilisation at Oxford University. 'I think that's why Branson has latched onto this ${ }^{24}$. A technological magic bullet would allow airlines to continue business as usual; failing that, the prize justifies Virgin's continued investments in air travel expansion on the grounds that Branson at least is generously funding the search for solutions.

Branson is explicit that his strategy demands faster growth of his airline business. Is this not paradoxical? Surely, the continued fast growth in air travel cannot be maintained 'without causing climatic disaster' - a quote from Friends of the Earth, the inclusion of which on Virgin Atlantic's website can only be described as facile ${ }^{25}$. Branson's guiding assumption is that only politicians and business leaders can act effectively to mitigate climate change; therefore, being an environmentally conscious citizen, his position as wealthy entrepreneur must be maintained. 'I can hear people saying,' he writes (2007b), "If $\mathrm{CO}_{2}$ emissions are the problem, why doesn't Richard Branson just stop his planes from flying?' But ... if we stopped, we'd leave a gap that somebody who might have no sense of responsibility at all would fill." This vision, Monbiot has remarked, depending as it does on the expansion of Virgin Atlantic, can be paraphrased as 'we must destroy the planet in order to save it ${ }^{, 26}$.

The Earth Challenge prize, one should concede, is dwarfed by Virgin's biofuels ventures. And what if biofuels proved to be Branson's desired magic bullet? Monbiot's jab could then be shrugged off. Sadly, this is improbable. For one thing, their viability as a jet fuel is open to doubt. The Intergovernmental Panel on Climate Change asserts that 'there would not appear to be any practical alternatives to kerosene-based fuels for commercial jet aircraft for the next several decades ${ }^{27}$. Branson places his hopes in 
ethanol, but this has a flashpoint of $12^{\circ} \mathrm{C}$, which 'would present major safety dangers,' according to researchers at Imperial College, London $^{28}$. In addition, it releases acetaldehyde at low power settings, 'bringing localised health problems around airports, especially for ground support staff.' Nor is bio-diesel suitable: at low temperatures, it turns cloudy or even forms a gel, blocking fuel filters and fuel lines. It is true that in February 2008 one Virgin Atlantic flight did include what Branson calls 'sustainable biofuel' in its fuel mix: $20 \%$ of the fuel of one of its four engines was made from the oil of coconuts and wild-growing babassu ${ }^{29}$. But one wonders, how 'sustainable' is this? Even leaving to one side the difficulties of flying on a $100 \%$ biofuel mix, were this possible, three million coconuts would be needed to fly just one aeroplane from London to Amsterdam. Yet 1,300 flights leave London's Heathrow airport each day. If all were biofuelled they would consume the oil of three billion coconuts (plus an indeterminate amount of babassu oil), and the total global production of coconuts would keep Heathrow going for 18 days (Reguly, 2008). Aware of these problems, Branson pleads that the airline industry must ultimately turn to algae in its search for a viable biofuel. Yet processing algae, environmentalists caution, 'may produce more carbon dioxide than is saved by using it as an alternative fuel. There are also concerns that algae will compete for fresh-water sources as the ponds evaporate and have to be topped up, ${ }^{30}$.

There is worse. Not only are biofuels unviable as an aviation fuel, the claims made on their behalf as a fuel for road transport face mounting criticism. (Indeed, between this article's submission in summer 2007 and its final edit in spring 2008, these have intensified into a clamour).

\section{Biofuels vs. the biosphere}

For all four of our companies, biofuels are an important part - and in some cases the key plank - of their climate change mitigation strategy. These four are not exceptions but belong to a fuel revolution. McDonald's in Britain is converting its fleet of trucks to run on bio-diesel. Auto-manufacturers, including Volvo and Volkswagen, are heavily involved, as are agribusinesses like Tate and Lyle. Political authorities encourage and direct the process. In his January 2007, State of the Union speech, President Bush proposed a law to mandate a petrol mixture of $20 \%$ ethanol over the next ten years. In the same month, the European Commission presented its biofuels blueprint, which proposed that $10 \%$ of transport (excluding aviation) across the EU should be biofuelled by 2020 . The Commission also plans to direct substantial funds towards biofuels research and development. For its part, the British government wants $5 \%$ of all transport fuel to be produced from crops by 2010. In his final budget as Chancellor, Gordon Brown announced he would extend tax rebates for biofuel until 2010 . He has personally urged train operators to switch to biofuel ${ }^{31}$.

Biofuel's detractors attack it at a number of levels. To start with the most obvious, its production competes with food crops. In 2006, more than one-third of the entire US maize crop went to ethanol for fuel, a 48\% increase over 2005. In 2007 and 2008, the shift to biofuels contributed to spikes in food prices that sparked rioting in cities across the world, prompting World Bank president Robert Zoellick to voice criticism of the dash to biofuel, while Jean Ziegler, the United Nations rapporteur on food rights, went so far as to call biofuel production 'a crime against humanity.' These problems could well worsen. If the EU fails to scrap its target of $10 \%$ biofuel in transport, fuel would require 
the equivalent of $20-40 \%$ of Europe's farmland. A study conducted in 2006 by Sarasin, a Swiss bank, placed 'the present limit for the environmentally and socially responsible use of biofuels at roughly $5 \%$ of current petrol and diesel consumption in the EU and US,' well below the targets of the EU and many governments (Monbiot, 2007). Furthermore, many biofuel feedstocks are heavy consumers of water; and their large-scale cropping leads to biodiversity loss, soil erosion and nutrient leaching. More pertinent to this article is that biofuels actually exacerbate climate change. Some feedstocks like as maize, can emit more $\mathrm{CO}_{2}$ than they save because processing consumes huge amounts of energy. Others, notably sugar cane and palm oil, accelerate $\mathrm{CO}_{2}$ release through deforestation and soil desiccation. As Doug Parr, chief UK scientist at Greenpeace, argues, 'If even 5\% of biofuels are sourced from wiping out existing ancient forests, you have lost all your carbon gain' (Holt-Giménez, 2007). Palm oil planting is the major cause of tropical deforestation in both Malaysia and Indonesia: much of the land being cleared is peat wetlands, which release carbon as the peat burns. A study by the Dutch scientific consultancy Delft Hydraulics found that the decomposing of peatland can release 70-100 tonnes of $\mathrm{CO}_{2}$ per hectare per year (Corporate Europe Observatory, 2007). The report shows that European use of Southeast Asian palm oil would generate upto ten times more $\mathrm{CO}_{2}$ than the equivalent emissions from fossil diesel. Indonesia alone is home to $60 \%$ of all tropical peatlands, and most of these are predicted to be drained in the coming decades as a by-product of its plans to increase palm-oil production $43-$ fold $^{32}$, releasing over 40 billion tones of carbon - the equivalent of around six years of global fossil fuel emissions. Malaysia, the world's largest producer of palm oil, has already lost $87 \%$ of its tropical forests and continues deforesting at a rate of 7\% per year (Holt-Giménez, 2007). Similar is taking place in Africa. Forests covered $40 \%$ of Uganda in the 1970 s, a figure that has slumped to $20 \%$ and is now in free fall. Sugar producers are lobbying (and allegedly bribing) the government to sanction the destruction of swathes of ostensibly protected rainforest. Protestors seeking to prevent this have been shot dead by Ugandan police $^{33}$. In Brazil, sugar cane is mainly grown at some distance from the rainforest - and Tesco cites this to justify its reliance upon Brazilian ethanol - but the exponential increase in sugar plantations pushes other land users into the forest, while soya, Brazil's other major biofuel crop, is grown on a vast scale in cleared forests, including the Amazon (Institute of Science in Society, 2006). Half of Tesco's bio-diesel is derived from palm oil and from soya, a crop that has directly caused the destruction of 21 million hectares of forest in Brazil and 14 million in Argentina. According to Dr Philip Fearnside, a researcher at Brazil's National Institute for Amazon Research (GRAIN, 2007), soya cultivation impacts on deforestation.

\footnotetext{
"by consuming cleared land, savannah and transitional forests, thereby pushing ranchers and slash-and-burn farmers ever deeper into the forest frontier. Soybean farming also provides a key economic and political impetus for new highways and infrastructure projects, which accelerate deforestation by other actors".
}

Concerns at these problems have prompted biofuel boosters to express concern or to switch tack. In April 2008, EU trade commissioner Peter Mandelson held firm to the EU strategy on biofuels, but advocated a certification scheme to ensure that only 'sustainable' feedstocks are used. This solution, although widely advocated, is a chimera, for certification cannot address the fact that increased demand for 'sustainable' feedstocks raises prices, encouraging increased sales of 'unsustainable' feedstocks to less 
scrupulous bidders. Others place their hopes in jatropha, a plant that does not require chemical fertilizers and need not compete with food crops (for it can be grown on marginal land), or to 'second generation' biofuels, notably cellulosic ethanol. Sourced from woodchips (or 'biomass waste'), using trees instead of food crops such products, it is argued, do not compete with food supplies. Jatropha's advocates, however, ignore the fact that it is a toxic, invasive weed, the yields of which are far higher when grown on prime, irrigated land - there have already been reports 'of farmers being dispossessed of fertile land by companies wanting to grow jatropha' (GRAIN, 2007). As for wood and 'biomass waste, ${ }^{34}$, cellulosic ethanol has yet to demonstrate any carbon savings. To become viable, major breakthroughs in plant physiology are required that would permit the efficient breakdown of cellulose and lignin. If these succeed, the monoculture tree plantations that result will still compete with food crops, deplete the soil and reduce ecological diversity.

Investments in biofuels by BP, Virgin, Tesco et al. will contribute to, and not ameliorate, global warming and the degradation of the biosphere. If this is their effect, the question arises: whence, then, their recent popularity? To begin with, it is worth recalling that the drive to biofuels kicked off in the early 1970s, not over climate change, but as a means of addressing the challenges of energy security and price. A second, greater, effort came in the late 1990s and 2000s, again for motives of energy security: i.e. to find methods of continuing 'business as usual' whilst lessening the need to source oil from potentially hostile regions. Geopolitics remains of paramount importance. In recent years, Washington has created an alliance with Brazil around the ethanol industry that is designed to counter Venezuela's oil-based influence in Latin America. A key figure in the US-Brazil alliance is Jeb Bush; he directs the Inter-American Ethanol Commission, an organisation charged with boosting the consumption and production of bio-ethanol.

For industrialists and politicians keen to be seen as green without directly addressing the need to reduce emissions, biofuels offer a quick fix. They are assisted in this by the terms of the Kyoto agreement, for it allows industrialised countries to claim that their use of biofuels reduces greenhouse gas emissions because the gases emitted during their production are largely released in countries of the South where Kyoto caps on emissions are absent (GRAIN, 2007). For some sectors, the 'green' appearance of biofuels is seen as justifying their continued expansion. A paradigm case is the automobile industry, for which biofuels offer the perfect pre-text for escaping the pressures that might otherwise emanate from regulators and public opinion to lower $\mathrm{CO}_{2}$-emission criteria for passenger cars or to produce fewer units. In the $\mathrm{EU}$, vehicles firms have been central to the political drive towards biofuels. Despite assurances of multiple stakeholder representation, the bodies invited to advise the European Commission are dominated by industries with biofuels interests: automobiles, oil, energy, biotech, foods and forestry. These organisations include the Advisory Research Council for Biofuels (BIOFRAC) and the European Biofuels Technology Platform (EBFTP). In the membership of BIOFRAC, the automotive industry was represented with more members than any other industry, while car companies, alongside oil giants, have the highest representation on EBFTP's steering committee. Its mission is 'to contribute to the development of cost-competitive worldclass biofuels technologies, to the creation of a healthy biofuels industry and to accelerate the deployment of biofuels in the European Union ${ }^{35}$. As reported by the Corporate Europe Observatory (2007), 


\begin{abstract}
"Volvo's Anders Roj chaired BIOFRAC and is now vice-chair of the EBFTP Steering committee. Volvo affirms its support for a greenhouse gas reduction target of $30 \%$ by 2020 for developed countries and for an EU greenhouse reduction commitment of $20 \%$ by 2020 . Yet, at the same time it creates vulnerability within the EU economy by threatening relocation: 'the competitiveness of in particular the energy intensive industry must be followed to avoid the possible moving out from the EU to third countries'. It also supports a binding target for agrofuels of $10 \%$ of all vehicle fuels by 2020 . This is a common corporate strategy, on one hand paying lip service to environmental measures while on the other warning that if those measures hit their pockets ... they will move away from Europe taking their jobs with them".
\end{abstract}

According to the newsletter of the EBFTP, the absence of broad representation is deliberate: 'an adequate balance of industry vs. research/public centres was established in order to preserve the Platform as an industry-led body,' and it defines its stakeholders as 'organisation[s] whose commercial or business activities' are affected by biofuels development ${ }^{36}$.

The biofuel sector, furthermore, offers new areas for business expansion. For agribusiness, suffering from low profit rates, government subsidies and mandated targets for biofuels are the perfect remedy (Holt-Giménez, 2007). Agribusinesses like Cargill are heavily involved. British Sugar is too; and it influenced EU policy through its membership of BIOFRAC. The biotech industry is also a major investor in biofuels. Genetically modified varieties of several crops now used as biofuel crops - maize, soya, oilseed rape - have met strong resistance to their use as food. The industry hopes that by promoting them as biofuels, and by helping to develop breakthrough 'second generation' technologies, their products will gain acceptance. Monsanto, Syngenta and others are investing heavily in biofuels. Again, biotech firms are policyshapers in the EU: the main European biotech lobby group, EuropaBio, was a member of BIOFRAC and is an active member of the EBFTP (Corporate Europe Observatory, 2007). Finally, for all this investment, finance is needed. Banks, financiers and investment funds are piling into the biofuels sector - amongst the pioneers were Goldman Sachs, Barclays and George Soros. Together with the other firms listed above, these form a powerful lobby pushing governments to support biofuels expansion.

\title{
4 Explaining the green shift
}

A recent survey of 350 of the world's top 500 firms (rated by market capitalisation) reveals that 'climate change and the various regulatory, policy and business responses to it are driving what amounts to a worldwide economic and industrial restructuring.' That restructuring, it continues, 'has already begun to redefine the very basis of competitive advantage and financial performance for both companies and their investors ${ }^{37}$. Although there is no shortage of rhetoric on climate change from PR departments and company directors, the flurry of activity in the boardrooms is not entirely cosmetic. Some executives are worried that climate chaos will adversely affect business, for example through higher insurance premiums or higher crop prices. Some are concerned about its impact on long-term growth, and with the instability that it will catalyse, through starvation, water shortages and resource wars. Such concerns are undoubtedly genuine. When, for example, Tesco's Terry Leahy counsels that 'if we fail to mitigate climate 
change, the consequences for all of us will be severe,' he means it; (although the seriousness with which climate change is treated is variable: a Branson, whose epiphany failed to check his activities promoting aviation, space tourism or even the Keep Concorde Flying campaign, is not an $\mathrm{Al}$ Gore).

Corporate leader' recognition of the dangers climate change pose to profitability and humanity is not the only reason behind the green shift. Another is alertness to the openings associated with it. These divide into two categories. First, there are business opportunities associated with climate chaos and its mitigation. 'The transition to a lowemissions global economy,' the Stern review points out (2007),

"will open many new opportunities across a wide range of industries and services. Markets for low carbon energy products are likely to be worth at least $\$ 500$ bn per year by 2050 , and perhaps much more. Individual companies and countries should position themselves to take advantage of these opportunities".

Some companies are developing crops resistant to extreme weather, renewables, or biofuels. Further down the line, others will find revenues in relocating, reconstructing and resupplying flooded or storm-damaged cities, or constructing flood defences. In business, first-mover advantage is considerable - witness, for example, the lead over rival electricfuel vehicles established by the Toyota Prius. Similarly, states that rapidly incentivise investment in low-carbon technologies are likely to see 'their' businesses reap large rewards. Secondly, as concern over climate change advances, opportunities associated with green branding swell. That a green image boosts sales has long been a staple in business-studies literature. 'The environment is the vehicle to greater profits in the 1990s,' Managing Service Quality told its readers over a decade ago (Denton, 1996);

\begin{abstract}
"organizations should comply with customer demands, [for], recent surveys show, consumers are willing to pay more for environmentally-friendly products. [Conversely], surveys by Gallup suggest that about half of their respondents in a 1990 poll stopped buying particular products because of the poor environmental image of the company ... The message is clear: companies need to make environmental concerns a top priority because consumers report that the environmental attributes of a product or service play a significant role in which products they buy and which they avoid. ... Companies which see the environment as a cost, rather than a chance to gain a competitive advantage, are missing the best opportunity of the 1990s".
\end{abstract}

Other surveys have suggested that a sizeable proportion of consumers are sufficiently committed to environmental goals that they are willing to pay a premium of at least $10 \%$ for 'green' products.

Knowledge of such trends is, of course, $\mathrm{ABC}$ in company boardrooms. As Terry Leahy (2007) frames the matter, if Tesco becomes 'a leader in helping to create a low-carbon economy' and gains recognition 'as a centre of expertise in how to run a green business, ... [it] will be rewarded with more custom and more loyalty and as a result will grow stronger.' It is safe to predict that these tendencies will strengthen. 'The branding of nature,' a recent article in Marketing Intelligence and Planning goes so far as to forecast, is 'a promising direction for research and practice. In societies in which nature experiences are becoming scarce while life becomes increasingly 'virtual' $\ldots$ the consumption of green products may serve as a substitute for real contact with nature'(Hartmann and Ibáñez, 2006).

The standard explanation of the corporate green shift is that environmentally concerned consumers buy green, and because marginal differences in image translate into 
large differences in turnover, rendering companies highly accountable to their customers, 'going green' becomes a vital brand asset. For this mechanism to be environmentally meaningful, however, customers must recognise 'green' behaviour, and there are grounds for doubting that they do. To give one example of fooled consumers that stands for many, some German utilities are tapping into a rapidly growing eco-conscious market simply by relabelling the electricity which they have for decades supplied from hydroelectric stations as 'special green energy' - which consumers, understandably but falsely, assume to derive from new investment in renewables. A recent report by WPP suggests that although $80 \%$ of consumers believe it is important that companies act in an environmentally friendly way, their understanding of what it means to be green is 'shallow, confused and easily swayed by company messages" ${ }^{38}$. The same survey found that the top 20 'green brands' included many surprising names, none more so than Shell, whose operations have in recent years become markedly more carbon intensive due to investments in Albertan tar sands and Chinese coal mining.

An alternative reading argues that the green shift is mostly 'greenwash'. Perhaps the most sophisticated version of this case has been elaborated by Heather Rogers. Given the severity of the contemporary ecological crisis, she observes, cultivating a green image becomes more demanding. Opinion polls show that while consumers are more likely to buy a product from a company that is known to have environmentally friendly practices, most will be guided primarily by cost and few will research a company's environmental record. The upshot is that although corporations profit from a green image,
"because fewer consumers actually buy eco-safe products, and an even smaller number delve into the reality of a company's practices, there is no need to truly transform production. Firms can cash in by merely jumping through the right hoops, which today include environmental claims certified by a third party, corporate investment in 'green' projects in partnership with non-profit environmental organizations, and offering eco-oriented consumer products".

Eco-commerce, Rogers concludes (2007), 'is a means for capital as a whole to avoid truly remaking itself, while giving the opposite impression. This misperception helps capital continue cultivating the ideology of individual responsibility linked to a market-based solution, pre-empting government regulation.'

The pre-emption - or influencing - of government regulation provides a further clue as to the nature and timing of the green shift. In early 2007, two articles in the US business press highlighted the changing attitude of US corporations to climate-change regulation. Companies are 'coming to the bargaining table for many reasons beyond the science,' reported Business Week (Carey, 2007);

"On Apr. 2 the US Supreme Court ruled that the Environmental Protection Agency can regulate $\mathrm{CO}_{2}$ as a pollutant. That could bring legal challenges and EPA-imposed mandatory curbs. 'The fear that the next Administration's EPA would have its hand on the lever is a great motivator,' says Natural Resources Defense Council attorney David D. Doniger. Plus, a growing patchwork of state carbon-emissions limits has prompted industries to push for a preemptive national law. And as energy executives face decisions, such as what kind of power plants to build for the next 40 years, they want regulatory certainty".

There will be regulation, CEOs recognise, and, before a law is drafted that overly prejudices their interests, they push 'pre-emptively' for business-friendly laws. The second piece, from The Wall Street Journal (Murray, 2007), extends the argument. 
Corporate leaders, it observes, recognise that limits on carbon dioxide emissions are now inevitable;

Indeed, they are already in place in Europe and coming soon to California and the Northeast. Better to get the federal government on board, they argue, so businesses can plan for the future. That's an especially potent argument for utilities, which have to make investment decisions today about serving customers $30-50$ years down the road. ... The 2006 election was a wake-up call for business leaders, reminding them they won't always have a businessfriendly government to protect them on this issue. ... Business leaders who sign on early will likely have more influence in crafting the all-important details of any legislation, which could determine who wins and who loses. ... In addition, CEOs are finding that a green hue helps keep them in good stead with employees, some activist investors and an environmentally conscious public. At a time when CEOs rank low in the public's esteem, many are happy for a chance to burnish their public profile.

Regulation inevitably privileges some interests over others. Therefore, the more prescient business leaders are saying, let's get early to the negotiating tables at which policymakers, corporations and international civil servants thrash out the rules.

The question is, what sort of framework - nationally and internationally - will govern the climate change regime? Will it be regulation-heavy? Will it be geared around taxation? Or will it be 'regulation lite,' organised through markets? Survey evidence suggests that most British businesses see government regulation as the most efficacious method of reducing emissions. Somewhat fewer believe taxes and tax breaks are key, while 'fewer than half thought voluntary agreements and market trading schemes were effective environmental tools ${ }^{39}$. This finding sits uneasily with the fact that the business sector has lobbied en bloc for a market regime and against heavier regulation. Why is this? Could it be that the promotion of 'regulation lite' arises from the attempt to square the imperative of tackling climate change with that of increasing profitability? There is certainly evidence to suggest that once a substantial regulatory framework became inevitable business leaders spotted a rent-seeking opportunity, a means by which the threat, while being formally acknowledged, could be reformulated to their advantage.

\section{Carbon trading: of lemons and low-hanging fruit}

Climate change policymaking since the mid-1990s, Matthews and Paterson (2005), have argued persuasively has essentially consisted of 'attempts to construct policies that create new sites of accumulation.' These include renewable energy (stimulating an existing market) and, more importantly, emissions trading (the creation of new markets and commodities). In the western USA, the EU, and at the global level, the policy regime centres on creating markets in emissions. The theory behind this momentous initiative is that the problem is a consequence of 'market failure,' i.e. that scarce resource (like clean air) will be excessively used or otherwise mistreated in the absence of appropriate market-mediated price signals. The term 'market failure' is predicated on the neoclassical assumption that the norm is a free market system and laissez-faire government; that if political intervention is required this should be taken as a signal that markets have not yet been properly constructed. Hence, the need for market expansion: the right to pollute must become a commodity; atmospheric pollution requires valorising. One early Emissions Trading Scheme (ETS) was launched by the EU in 2005, involving some 
11,500 installations. It connects into two others that were inaugurated following negotiations at Kyoto: the CDM and the Joint Implementation Mechanism. As these markets become actualised, growing numbers of corporations recognise their inevitability and consider how to play them and - for these are highly politicised markets - how to lobby for favourable terms.

The advocates of carbon trading justify it in terms of efficiency: it allows the cheapest cost of reducing emissions to be found. The market sets a price for the right to emit one tonne of $\mathrm{CO}_{2}$ (or other greenhouse gases); if the price is high enough, companies will find ways to cut emissions. Market schemes thus encourage the development of innovative abatement technologies - unlike a carbon tax, which, according to Mark Maslin (2004), 'provides an incentive only to adjust production levels, which generally benefits neither business nor society.' But criticisms of emissions trading abound. Problems arise from the fact that measurements, largely provided by the emitters themselves, are notoriously 'flexible'. A Christian Aid report in 2007 revealed that Britain's biggest businesses failed to disclose almost 200 million tonnes of emissions - more than the entire annual emissions of Pakistan and Greece combined - significantly affecting the extent of Britain's perceived contribution to global warming ${ }^{40}$. Only 16 of Britain's top 100 listed companies currently meet even the most elementary official emissions reporting guidelines. This is an inherent and general problem of emissions trading. As the Transnational Institute and Carbon Trade Watch point out (McGarr, 2005), such markets

\begin{abstract}
"in effect privatise the problem of air-pollution. Government and communities lose control over environmental protections, placing it in the hands of the polluters. When the incentive to reduce emissions is profit and costeffectiveness, there is incredible pressure to cheat by overestimating reductions, while underestimating emissions."
\end{abstract}

Both buyers and sellers of carbon credits have an interest in inflating the number generated by any given project. 'With a bit of judicious accounting,' Lohmann observes, 'a company investing in foreign 'carbon-saving' projects can increase fossil emissions both at home and abroad while claiming to make reductions in both locations.' As a result of the absence of accurate verification, 'the project-based credit market runs the risk of becoming what George Akerlof calls a self-destructing 'lemons market." The quality of the goods traded being uncertain, 'lemons' can be readily off-loaded onto the market 'and buyers won't pay the prices demanded by sellers of higher-quality products' (Lohmann, 2006).

As with the offsets discussed above, carbon markets enable corporations to earn credits by sponsoring schemes elsewhere that supposedly reduce emissions. In such cases, a credit can be earned based on a calculation of the hypothetical difference between what has happened and what might otherwise have occurred. These credits can then be used to increase the corporation's own emissions without facing a penalty. Such schemes are open to abuse over who decides what would otherwise have transpired and who performs the resulting calculation. The CDM, writes Paul McGarr (2005), allows a corporation to

"sponsor a plantation in a poor country, and claim that if this hadn't been done more carbon dioxide would have gone into the atmosphere, on the grounds that trees lock up carbon. Another example could be a corporation investing in some electricity generation project involving, say, hydroelectric power and dams, and claiming that otherwise fossil fuels would have been burned and put more carbon dioxide into the atmosphere." 
Far from providing real alternatives to fossil-fuel consumption, schemes of this sort simply sanction emissions expansion.

In Larry Lohmann's important treatise on carbon trading (2006), a persuasive case is made that markets do not in fact represent an efficient method of reducing emissions. The essential flaw is that carbon trading treats every tonne of carbon alike. Leaving aside any social justice implications (the same price is assigned to 'basic needs $\mathrm{CO}_{2}$ ' as to 'luxuries $\mathrm{CO}_{2}$ '), this negates efficiency, for savings made by introducing a radical new renewable technology or way of organising social life that would lead to vastly multiplied future cuts are deemed equal to those stemming from routine efficiency improvements that should have been made long ago. The cuts made today will influence the potential for future reductions, Lohmann points out, but markets reward the cheapest, rather than those with the most effective long-term consequences. He gives the example of a company that could either reduce emissions by installing an end-of-pipe technology, necessitating an initial outlay of 100,000 followed by 1,000 per year in operational costs, or, for 200,000, re-engineer its entire industrial process in a way that reduces its need for fossil fuels, generating cost savings of 1,000 per year. The latter solution would be better for the climate and, over the long run, cheaper. Yet a company choosing the former would benefit most from a trading system, by selling permits cheaply during the initial years. Emissions trading even provide incentives for those polluters for which introducing emissions-reducing technological changes are more expensive not to reduce emissions: the rational choice for them, rather, is to buy permits. The effect is to discriminate against costlier forms of innovation, even if they are more effective. A further drawback is that the accounting procedures in carbon trading actually set up perverse incentives for carbon project proponents to emit more greenhouse gases today in order that their projects appear to save more tomorrow.

In practice, the record of carbon trading has been dismal. The EU ETS was the first fully functioning trading scheme and, given the advantages that accrue to 'first-movers,' Brussels is a keen proponent of the universalisation of such schemes. However, already in its early stages, only a minority of companies believed that it would result in any emissions reductions, and they were right (Lohmann, 2006). Lacking the political will to tackle big emitters, the European Commission over-allocated carbon permits. British firms, for example, were given the rights to emit as much as they had in the previous five years (Lohmann, 2006). The price of permits went into free fall.

The biggest gains from the EU ETS have been scored by corporations with large allocations which can effect emissions cuts and sell permits when the price is high, and then expand emissions when it falls. The system, Michael Dorsey has revealed, 'financially rewarded companies - mainly petroleum, natural gas and electricity generators - that disproportionately emit carbon dioxide. ... In fall 2006, a Citigroup report concluded that the continent's biggest polluters had been the winners, with consumers the losers ${ }^{41}$. In particular, energy companies benefited, because they incorporate the market value of permits - which they receive gratis - into the price of their product. A 2005 report by IPA Energy Consulting found that Britain's six electricity generators stood to earn some $£ 800 \mathrm{~m}$ in each of the first three years of the scheme, while the EU's four biggest power firms, according to Germany's Environment Minister, profited from the first round of the ETS to the tune of $€ 6-8$ billion. The next round of the ETS looks no more promising than the first. By 2012, utilities in Britain and four other European countries stand to gain windfall profits of up to $€ 71 \mathrm{bn}$, despite investing heavily in new coal-fired power plants (Gow, 2008). The irrationality of the ETS has 
been demonstrated by a number of recent studies, the most striking of which, by Ben Schlemmermeier, director of the LBD consultancy in Berlin, and Professor Hans-Peter Schwintowski, Director of the Institute for Energy and Competition Law at Humboldt University, showed that, in 2005 , German consumers paid $€ 1100$ for each tonne of $\mathrm{CO}_{2}$ saved through the ETS, a figure that was projected to rise in 2007 and 2008 to over $€ 2000$. An equivalent volume saved by investing in renewable energy, the same report demonstrated, costs only $€ 57^{42}$.

When one turns to the global level, i.e. to the Kyoto schemes, one discovers criticisms that are similar and no less serious. To begin with, the targets are set very low: the cuts in emissions that Kyoto envisages, even if fully implemented, will do virtually nothing to halt global warming. Kyoto does not include aviation emissions, and allows forest and agricultural land to be counted as carbon sinks, which may save some forest from destruction, but at the price of sanctioning the principle that such practices are valid - and profitable - alternatives to emissions reduction. As with the EU ETS, Kyoto's rules allow corporations in developed countries to exceed emissions targets by buying carbon credits or investing in offset schemes which - as in the case of Jindal discussed above frequently reduce only hypothetical emissions. In theory, a country will 'be able to meet $100 \%$ of its Kyoto reduction commitments through purchasing credits in the market rather than reducing climate change emissions at source ${ }^{43}$. A further problem with this and other ETS is their operating costs. Pace Maslin, the same or superior effects could be achieved at far lower administrative expense through a tax on non-renewable energy. A carbon tax is seen even by many neo-liberal economists, such as Martin Wolf of the Financial Times, as a more efficient means of encouraging businesses to develop low carbon emissions technology ${ }^{44}$.

There is growing recognition that the carbon trading experiment has failed. Quoting Tom Burke of environment lobby group E3G, a recent Reuters report (Lovell, 2007) puts it starkly:

"The policy instrument of choice pretty well everywhere is a price for carbon, and it is not going to work, ... the vital incentive is supposed to be provided by achieving a high price for carbon, from which all else would follow. Neither has happened and time is running out".

Oxford University economics professor Dieter Helm concurs (Lovell, 2007): 'The price of carbon has had virtually no effect on the market so far and virtually no effect on climate change.' Together, the EU and Kyoto schemes have generated a global carbon trade worth billions of dollars but have had a negligible effect on emissions. Evidence collected by the Guardian (Davies, 2007) suggests that, to date,

"both markets have earned fortunes for speculators and for some of the companies which produce most greenhouse gases and yet, through a combination of teething troubles and multiple forms of malpractice and possibly fraud, they have delivered little or no benefit for the environment".

Yet the problem lies deeper than teething troubles and fraud. Quite simply, as Jim Watson of Sussex University's Energy Group points out, 'If you rely too much on the carbon price you give people the option of buying their way out of it.' The oil price shocks of the 1970s, he adds (Lovell, 2007), 'didn't wean us off oil, so why should we believe that a high carbon price will wean us off carbon?'

As to how this sorry situation could arise, the answer lies in part in prevailing neoliberal assumptions: that the response to market failure is market expansion, that 
addressing climate change requires commodifying the right to pollute. But it also results from corporate support for market solutions. In this, BP's John Browne was a pioneer. His environmentally conscious image notwithstanding, he was ever careful to warn that investing too heavily in green processes and products would be foolhardy - 'Business is about doing business, it's not a surrogate for government or public service' (Anon. 2006). Climate change, he foresaw, would bring money-making opportunities. In 2000, BP pledged to reduce its carbon emissions by $10 \%$, and introduced an internal trading system to this end. This did help the company make the easy one-third of the cuts required relatively cheaply but, in attempting to make the more difficult cuts, it found it cheaper to avoid more radical change through offsetting. By 2002, Lohmann reports (2006), 'the company expected half of its so-called 'emissions reductions' to come from credits bought in from outside. At no point was there any move toward genuinely innovative technology.' In spite of this unpromising experience, BP has strongly supported the generalisation of emissions trading to the global system. The reason for this, one cannot but suspect, is venal: carbon trading systems offer a fertile ground for rent-seeking, i.e. harvesting values through manipulation of the economic environment, with investment in lawyers, lobbying, PR campaigns and accountants (because emissions-trading regulators must rely on private firms for information) rather than producing and selling commodities (Lohmann, 2006). The outcome for BP and for other big polluters, has been a triumph. As Homan Jenkins reports, in the Wall Street Journal,

\begin{abstract}
"General Electric, DuPont, Alcoa, Caterpillar and other industrial pigpens this week endorsed cap-and-trade limits on carbon dioxide, which would turn their established habit of using the atmosphere as a free waste disposal into a property right, worth billions. Talk about a low-hanging fruit. They are accustomed to treating carbon dumping as a gimme. Now they'd at least be in a position to get paid for dumping less. Their hero is retiring BP chief John Browne, who turned his little oil company into a big oil company, engaged in cost cutting (which he called 'emissions cuts') and set about using public policy to get his shareholders compensated twice for these cuts" ${ }^{45}$.
\end{abstract}

As emissions markets become generalised, vested interests build up in support of them, forming obstacles to radical reform. 'The trouble is,' Burke laments (Lovell, 2007), 'there are a lot of people out there making a lot of money out of carbon trading and who want to perfect the market rather than press for the changes that are actually needed.'

\title{
6 Conclusions
}

In recent years, elite thinking on climate change has been transformed. The dominant strategy for many years was denial, masked as 'scepticism,' and was committed to preventing the formation of an effective policy regime. It is now eclipsed by a new approach. Exemplified by the likes of BP, M\&S and Virgin, corporations are investing in renewables, biofuels, offsets, waste reduction and/or carbon labelling, and are influencing public policy through advising, lobbying and campaigning. Amongst the reasons for this 'green shift,' I would include the dawning awareness of many corporate executives that global warming is a major problem, one that may adversely affect business prospects and will certainly generate social problems and political instability. As recognition grows of the business opportunities associated with climate chaos and with attempts to mitigate it, of the benefits of green branding and securing a better position at negotiating tables on 
environment-related policy, a critical mass is reached when large numbers of companies perceive a strong need to be seen as green.

The green shift has taken on its distinctive contours due to the attempt by soi-disant green CEOs - Branson, Rupert Murdoch and their ilk - to square their concern for the environment with the need to perform for shareholders. The shift has enabled corporate and political elites to co-opt and control discussion on climate change, and to construct a policy framework that does little to reduce emissions, but provides them with further opportunities. The 'black' in Leahy's slogan - 'green is the new black' - references not only environmental vogue, but also the colour of the company's accounts. The argument of this article is that narrow financial considerations act as trump cards, keeping climatechange mitigation strategies to those that are compatible with 'business as usual.' On closer examination, these were shown to be far less impressive than they appear, frequently guilty of spin or barefaced deception, and in many cases actually harmful - or, as with carbon labelling, marginally helpful but contributing to counterproductive phenomena like the individualisation of ecological problems. Too often, green rhetoric obscures quite different motives: How can we steal a march on rivals?, What enzymes can we patent that might be crucial for second generation biofuels? and the like. For corporate executives and politicians alike, the mentality involved is too often a complacent faith in technology: the problem can be solved through new or improved products or energy saving (A representative example is Tony Blair's justification of the expansion of long-range air travel: 'I think we need to look at how you make air travel more energy efficient, how you develop the new fuels that will allow us to burn less energy and emit less. ... for example ... the new frames for aircraft, they are far more energy efficient ${ }^{46}$ ). But, the most egregious example of narrow business interests trumping ecological rationality occurs in the engineering of a policy framework that has fashioned the Earth's carbon-cycling capacity into property rights that are awarded to the corporate sector, including the most high-polluting corporations. The undignified spectacle of competitive rent-seeking witnessed in the EU and Kyoto trading schemes has enriched the big emitters but does nothing to prevent climate chaos. The current marketcentred policy regime is counterproductive. A more effective and more just strategy would involve concerted state intervention focused upon investment in public transport, housing and renewable energy, coupled with regulatory measures to radically reduce fossil-fuel use.

Please check the inserted page range in reference 'Anon. (2006)'.

\section{$\mathrm{AU}$ :}

Please provide complete details for highlighted references.

\section{References}

Anon. (2006) 'Green is green at general electric; Is Jeff Immelt the man to pull 'Ecomagination' off?', Strategic Direction, Vol. 22, pp.21-23.

Branson, R. (2007a) Screw it, let's do it; Lessons in Life and Business. London, UK: Virgin Books. Branson, R. (2007b) Losing My Virginity: The Autobiography. London, UK: Virgin Books.

Carey, J. (2007) 'With the skeptics almost silenced, businesses are fighting over how to cut carbon emissions,' Business Week (April).

Corporate Europe Observatory (2007) The EU's Agrofuel Folly: Policy Capture by Corporate Interests (June).

Cronin, D. (2008) 'Fuelling the food crisis,' The Guardian (April 15).

Davies, N. (2007) 'The Truth About Kyoto,' The Guardian (June 2).
AU:

Please check the author name in reference 'Anon. (2006)'

AU:

The reference

'Cronin (2008)' has been provided in the list but not cited. Please check. 
Denton, K. (1996) 'Managing pollution efforts: how to turn pollution into profits,' Managing Service Quality, Vol. 6, pp.26-29.

Gow, D. (2008) ' $\mathrm{CO}_{2}$ trade to bring $£ 57$ bn windfall,' The Guardian (April 7).

GRAIN (2007) Seedling; Biodiversity, Rights and Livelihood, Agrofuels special issue (July).

Harris-White, B. and Elinor Harris (2007) 'Unsustainable Capitalism: the politics of renewable energy in the UK,' Socialist Register. New York, NY: Monthly Review Books.

Hartmann, P. and Ibáñez, V.A. (2006) 'Green value added,' Marketing Intelligence and Planning, Vol. 24, pp.673-680.

Holt-Giménez, E. (2007) 'Biofuels: The Five Myths of the Agro-fuels Transition,' Global Research (30 June).

Institute of Science in Society (2006) Which Energy?

Terry Leahy (2007) 'You don't need to be an eco-warrior to realise green is the new black in the City,' Daily Telegraph, web edition (19 April).

Lohmann, L. (2006) 'Carbon Trading; A critical conversation on climate change, privatisation and power,' Development Dialogue No. 48 (September).

Lovell, J. (2007) Carbon price is poor weapon against climate change. Available at: www.reuters.com (24 September).

Maslin, M. (2004) Global Warming. Oxford, UK: Oxford University Press.

Matthews, K. and Paterson, M. (2005) 'Boom or bust? The political-economic engine behind the drive for climate change policy,' Global Change, Peace and Security, Vol. 17, pp.59-75.

McGarr, P. (2005) 'Capitalism and Climate Change', International Socialism, 107.

Milmo, C. (2007) 'The biggest environmental crime in history,' Independent (10 December).

Monbiot, G. (2007) 'Just a lot of hot air', The Guardian (5 March).

Murray, A. (2007) 'Why key executives are warming to legislation on climate change', Wall Street Journal, 7.2.

Noble, D. (2007) 'The corporate climate coup', ZNet (8 May).

Reguly, E. (2008) Branson goes coconuts. Available at: www.theglobeandmail.com (28 February).

Rogers, H. (2007) 'Garbage capitalism's green commerce,' Socialist Register. New York, NY: Monthly Review Press.

Stern, N. (2007) The Economics of Climate Change. Cambridge, MA: Cambridge University Press.

Warr, K. (2006) Climate Change. Milton, Keynes: Open University Press.

\section{Notes}

${ }^{1}$ Guardian 04.05.2007 pp.30-31.

2، The world in our hands,' Shell-sponsored section in the Guardian 'Climate change; Challenging business' 27 June 2007.

${ }^{3}$ Financial Times, 24.05.2007, p.28.

${ }^{4}$ For a critique of Noble, see Dale (2007).

${ }^{5}$ Guardian, 04.05.2007.

${ }^{6}$ www.indymedia.org.uk/en/2007/04/368045.html, accessed 05.05.2008.

${ }^{7}$ Guardian 27.6.2007; 'D1-BP Fuel set to extract bio-diesel from jatropha,' www.icis.com, accessed 14.02.2008.

${ }^{8}$ www.marksandspencer.com/gp/, accessed 12.09.2007

${ }^{9}$ Guardian, 04.05.2007 pp.30-31.

${ }^{10}$ Sunday Times, 29.04.2007.

${ }^{11}$ www.virgin-atlantic.com/en/gb/allaboutus/environment/bransonpledge.jsp, accessed 05.05.2008.

AU:

Please check the inserted volume number and page range in reference

'Matthews and Paterson (2005)'. 
${ }^{12}$ www.populuslimited.com/uploads/download_pdf-230407-Populus-Concerned-ConsumerIndex.pdf, accessed 05.05.2008.

${ }^{13}$ According to Henderson Global Investors, cited in Harris-White and Harris (2007).

${ }^{14}$ Financial Times, 27.06.2007, p.21.

${ }^{15}$ Sunday Herald, web edition, 19.07.2007.

${ }^{16}$ www.terradaily.com/reports/British_Food_Retailers_Carving_Out_Green_Future_999.html, accessed 05.05.2008.

${ }^{17}$ For this formulation, my thanks to Eva Barker.

${ }^{18}$ Guardian 19.06.2007 p.28.

${ }^{19}$ This paragraph draws upon materials from www.corporatewatch.org.uk and www.turnuptheheat .org.

${ }^{20}$ www.turnuptheheat.org/?page_id=13, accessed 05.05.2008.

${ }^{21}$ news.bbc.co.uk/2/hi/science/nature/3612739.stm, accessed 05.05.2008.

${ }^{22}$ Letter to Independent newspaper, 14.05.2007, by twelve scientists at the National Oceanography Centre, Southampton.

${ }^{23}$ www.realclimate.org/index.php/archives/2007/05/thin-soup-and-a-thin-story/\#more-440, accessed 05.05.2008.

${ }^{24}$ www.iht.com/articles/2007/02/09/business/climate.php, accessed 05.05.2008.

${ }^{25}$ www.virgin-atlantic.com/en/gb/allaboutus/environment/bransonpledge.jsp, accessed 05.05.2008.

${ }^{26}$ www.turnuptheheat.org/?page id $=11$, accessed 05.05 .2008 . I leave to one side Virgin Trains' much-trumpeted biofuels trial, which was abandoned in 2007 after the group lost its 'CrossCountry' franchise.

${ }^{27}$ ibid.

${ }^{28}$ ibid.

${ }^{29}$ 'Branson's Coconut Airways,' The Guardian 25.02.2008.

${ }^{30}$ ibid.

${ }^{31}$ Financial Times, 08.06.2007, p.4.

${ }^{32}$ Although some of the land earmarked for plantations is felled for lumber and then not planted (GRAIN 2007).

${ }^{33}$ Independent 10.07.2007, p.25.

${ }^{34}$ 'Biomass waste' is a misnomer: 'it is the organic matter that you have to put back after harvest in order to maintain the soil's fertility.' (GRAIN 2007).

${ }^{35}$ www.biofuelstp.eu/downloads/Steps_to_TP_LCJS.pdf, accessed 05.05.2008.

${ }^{36}$ www.biofuelstp.eu/downloads/Steps_to_TP_LCJS.pdf, accessed 05.05.2008. See also Corporate Europe Observatory (2007)

${ }^{37}$ 'Climate change spurs industry restructuring,' www.reuters.com, 24.09.2007.

${ }^{38}$ Guardian, 04.05.2007.

${ }^{39}$ Financial Times, 5.7.2007.

${ }^{40}$ Guardian, 19.02.2007. Christian Aid's calculations refer to basics, like office lighting, and don't take account of investment or supply chains.

${ }^{41}$ Los Angeles Times, 01.04.2007.

${ }^{42}$ www.energieverbraucher.de/de/Umwelt_und_Politik/Umwelt_und_Klima/site_468/, accessed 05.05.2008

${ }^{43}$ Transnational Institute and Carbon Trade Watch, cited in McGarr (2005).

${ }^{44}$ Financial Times, 15.11.2006.

${ }^{45}$ 'Decoding Climate Politics,' Wall Street Journal, 24.1.2007.

${ }^{46}$ Guardian, 09.01.2006. 